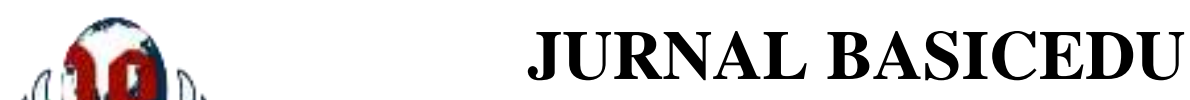

Volume 5 Nomor 6 Tahun 2021 Halaman 6453 - 6463

Research \& Learning in Elementary Education

https://jbasic.org/index.php/basicedu

P $\frac{\text { UVERSITAS }}{A H L A M A N}$

\title{
Efektivitas Penggunaan Model Blended Lerning dalam Meningkatkan Motivasi dan Hasil Belajar Siswa MI Darul Hikmah Bone
}

\author{
Mustanil $^{1}$, M. Samsul Hady ${ }^{2}$, A. Nurul Kawakip ${ }^{3}$ \\ Magister Pendidikan Guru Madrasah Ibtidaiyah, Universitas Islam Negeri Maulana Malik Ibrahim Malang ${ }^{1,2,3}$ \\ E-mail: tanilmus22@gmail.com¹, emsamsulhady@pai-uin-malang.co.id ${ }^{2}, \underline{\text { akhmad.nurul@pai.uin- }}$ \\ $\underline{\text { malang.co.id }}{ }^{3}$
}

\begin{abstract}
Abstrak
Motivasi belajar merupakan faktor pendukung sekaligus faktor penghambat dalam mencapai tujuan pembelajaran. Motivasi belajar merupakan satu hal yang sangat berpengaruh terhadap hasil belajar. Tujuan penelitian ini adalah untuk mengetahui efektivitas penggunaan model blended learning dalam meningkatkan hasil belajar melalui motivasi belajar siswa. Penelitian ini dilaksanakan pada pembelajaran tematik di kelas IV MI Darul Hikmah Bone dengan sampel yang terdiri dari 48 peserta didik. Jenis penelitian ini merupakan penelitian ex-post facto dengan pendekatan kuantitatif. Teknik pengumpulan data yang digunakan adalah dokumentasi, angket dan soal. Teknik analisis data yang digunakan meliputi outer model, inner model serta bootstrapping dengan bantuan smartPLS versi 3.0. Berdasarkan hasil analisis yang telah dilakukan peneliti, menunjukkan nilai $P$ value pengaruh tidak langsung $\mathrm{X} \rightarrow \mathrm{Y} 1 \rightarrow \mathrm{Y} 2$ sebesar 0,002 dengan T statistik 3,079, nilai $P$ value $<0,05$, T statistic $>1,96$ menunjukkan bahwa secara signifikan $\mathrm{X}$ dapat berpengaruh tidak langsung terhadap Y2 melalui Y1, dengan kata lain, motivasi belajar (Y1) dapat me-Mediasi pengaruh (blended learning (X) terhadap hasil belajar (Y2). Jadi, dapat disimpulkan bahwa penggunaan model blended learning efektif meningkatkan hasil belajar melalui motivasi belajar siswa.
\end{abstract}

Kata Kunci: Blended Learning, Motivasi Belajar, Hasil Belajar.

\begin{abstract}
Learning motivation is a supporting factor as well as an inhibiting factor in achieving learning objectives. Learning motivation is one thing that is very influential on learning outcomes. The purpose of this study was to determine the effectiveness of the use of the blended learning model in improving learning outcomes through student learning motivation. This research was conducted on thematic learning in class IV MI Darul Hikmah Bone with a sample consisting of 48 students. This type of research is an ex-post facto research with a quantitative approach. Data collection techniques used are documentation, questionnaires and questions. The data analysis techniques used include the outer model, inner model and bootstrapping with the help of smartPLS version 3.0. Based on the results of the analysis that has been carried out by researchers, it shows that the $P$ value of the indirect effect of $X \rightarrow Y 1 \rightarrow Y 2$ is 0.002 with a $T$ statistic of 3.079, $P$ value <0.05, $T$ statistic > 1.96 indicates that $X$ can have an indirect effect. on Y2 through $Y 1$, in other words, learning motivation (Y1) can mediate the effect (blended learning $(X)$ on learning outcomes (Y2). So, it can be concluded that the use of the blended learning model is effective in improving learning outcomes through student learning motivation.
\end{abstract}

Keywords: Blended Learning, Learning Motivation, Learning Outcomes.

Copyright (c) 2021 Mustanil, M. Samsul Hady, A. Nurul Kawakip

Corresponding author :

Email: tanilmus22@gmail.com

DOI : https://doi.org/10.31004/basicedu.v5i6.1687

ISSN 2580-3735 (Media Cetak)

ISSN 2580-1147 (Media Online)

Jurnal Basicedu Vol 5 No 6 Tahun 2021

p-ISSN 2580-3735 e-ISSN 2580-1147 
6454 Efektivitas Penggunaan Model Blended Lerning dalam Meningkatkan Motivasi dan Hasil Belajar Siswa MI Darul Hikmah Bone - Mustanil, M. Samsul Hady, A. Nurul Kawakip

DOI

: https://doi.org/10.31004/basicedu.v5i6.1687

\section{PENDAHULUAN}

Motivasi belajar merupakan faktor pendukung dan faktor penghambat bagi peserta didik dalam belajar. Masalah motivasi belajar sudah ada sejak zaman dahulu, namun hal tersebut sampai sekarang belum saja terselesaikan dengan sempurna karena dipengaruhi oleh beberapa faktor, baik faktor internal maupun faktor eksternal. Motivasi belajar siswa sangat berpengaruh terhadap kesuksesan pembelajaran di kelas. (Mafirah, 2020).

Motivasi dapat diartikan sebagai dorongan yang memungkinkan siswa untuk bertindak atau melakukan sesuatu. Motivasi adalah suatu keadaan yang terdapat dalam diri seseorang yang menyebabkan seseorang melakukan kegiatan tertentu untuk mencapai tujuan tertentu. Dengan demikian, motivasi muncul dari dalam diri seseorang karena dorongan untuk mencapai tujuan. Frededirc J.Mc Donald sebagaimana dikutip dari buku (Sanjaya, 2008) mengemukakan:"Motivation is an energy change whitin the person characterized by effectivearausal and anticipatory goal reaction". Jadi, motivasi adalah suatu perubahan energi dalam diri seseorang yang ditandai oleh munculnya perasaan dan reaksi untuk mencapai tujuan. Motivasi adalah kekuatan yang menjadi pendorong kegiatan individu, yang menunjukkan suatu kondisi dalam diri individu yang mendorong atau menggerakkan individu tersebut malakukan kegiatan mencapai suatu tujuan (Sukmadinata, 2009).

Menurut Witherington dalam bukunya Nana Syaodih Sukmadinata mengemukakan bahwa belajar merupakan perubahan dalam kepribadian, yang dimanifestasikan sebagai pola-pola respons yang baru yang berbentuk keterampilan, sikap, kebiasaan, pengetahuan, dan kecakapan. Pendapat yang hampir sama dikemukakan oleh Crow and Crow dan Hilgard. Menurut Crow and Crow belajar adalah diperolehnya kebiasaan-kebiasaan, pengetahuan dan sikap baru, sedangkan menurut Hilgard (Sukmadinata, 2009) belajar adalah suatu proses dimana suatu perilaku muncul atau berubah karena adanya respons terhadap suatu situasi.

Dapat disimpulkan bahwa motivasi adalah daya penggerak atau keinginan seseorang untuk melakukan suatu perbuatan, sedangkan belajar adalah proses untuk membuat orang dari tidak tahu menjadi tahu. Jadi, motivasi belajar adalah daya penggerak atau keinginan siswa untuk tahu dan mempelajari suatu hal yang baru.

Rendahnya motivasi belajar siswa akan menghambat tercapainya hasil belajar yang baik dan tujuan pendidikan. Peserta didik yang tidak memiliki motivasi dalam dirinya akan gagal walaupun ia memiliki intelegensi yang tinggi serta hasil belajar yang diperoleh tidak akan maksimal (Santoso, 2016). Dalam penelitian Darmawati dikatakan bahwa terdapat pengaruh secara simultan antara motivasi dan gaya belajar siswa terhadap prestasi belajar siswa. Semakin tinggi motivasi dan gaya belajar semakin tinggi prestasi belajar siswa yang dicapai, sebaliknya semakin rendah motivasi belajar dan gaya belajar siswa maka semakin rendah prestasi belajar yang diperoleh (Darmawati, 2013). Selanjutnya hasil penelitian Hamdu dan Agustina mengatakan bahwa motivasi merupakan satu hal yang sangat berpengaruh terhadap kesuksesan aktifitas pembelajaran peserta didik. Jika tidak memiliki motivasi, maka proses pembelajaran di kelas sulit untuk mencapai kesuksesan yang optimum (Agustina, 2011).

Kondisi di lapangan saat ini terkait motivasi belajar khususnya MI Darul Hikmah Bone tidak bisa terlepas dari pengaruh pandemi covid-19. Setelah berbincang-bincang dengan beberapa orang tua wali dan Herawati, S.Pd. selaku wali kelas IV serta melihat sendiri keadaan yang ada bahwa dengan adanya pandemi ini memaksa siswa untuk belajar di rumah saja dan atau belajar di sekolah hanya beberapa hari dalam satu minggu, hal tersebut mengakibatkan motivasi belajar peserta didik menurun seperti tidak mengumpulkan tugas tepat waktu, mudah putus asa ketika mendapat tugas yang sulit, PR dikerjakan oleh orangtuanya, tidak rutin melihat tugas yang dikirim guru melalui via WA grup, mengerjakan tugas asal-asalan dan lebih banyak menghabiskan waktu bermain game. Hal ini berdampak pada hasil belajar siswa, sebanyak 65\% yang mendapat nilai di bawah Kriteria Ketuntasan Minimal (KKM pembelajaran tematik kelas IV MI Darul Hikmah $=72$ ). Tentu hal tersebut menjadi perhatian bagi para pendidik dan orang tua wali. 
6455 Efektivitas Penggunaan Model Blended Lerning dalam Meningkatkan Motivasi dan Hasil Belajar Siswa MI Darul Hikmah Bone - Mustanil, M. Samsul Hady, A. Nurul Kawakip

DOI : https://doi.org/10.31004/basicedu.v5i6.1687

Hasil belajar adalah hasil dari proses evaluasi siswa yang mencakup tiga aspek yaitu afektif, kognitif dan psikomotorik setelah peserta didik mengikuti pembelajaran dimana hasil belajar tersebut bisa diukur dengan alat instrument yang sesuai atau relevan. Terjadinya perubahan tingkah laku dari tidak baik menjadi baik yang terjadi setelah proses pembelajaran merupakan bentuk dari pemahaman perilaku, persepsi, motivasi atau perpaduan dari komponen tersebut serta kualitas belajar seseorang ditentukan oleh pengalamanpengalaman yang didapatkan ketika berhubungan dengan lingkungan sekitarnya (Winataputra, 2008). Peran motivasi dalam memperjelas tujuan belajar erat kaitannya dengan kemaknaan belajar. Hal tersebut sangat berpengaruh terhadap hasil belajar siswa.

Hamalik mengatakan bahwa hasil belajar adalah terjadinya perubahan tingkah laku pada diri seseorang yang dapat diamati dan diukur dari segi aspek kognitif, afektif dan psikomotorik (Tim Penyusun Pusat Bahasa (Mendikbud), 2007). Menurut (Sudjana, 2011) hasil belajar merupakan kemampuan yang dimiliki siswa setelah menerima pengalaman dalam belajarnya. Pengalaman ini akan menghasilkan keterampilan, pengetahuan, dan sikap atau yang sering dikenal dengan sebutan kognitif, afektif dan psikomotorik (Purwanto, 2016). Hasil belajar merupakan kemampuan yang diperoleh individu setelah proses belajar berlangsung, yang dapat memberikan perubahan tingkah laku baik pengetahuan, pemahaman, sikap dan keterampilan siswa sehingga menjadi lebih baik dari sebelumnya (Purwanto, 2002). Hasil belajar adalah perubahan perilaku yang diperoleh siswa setelah mengalami aktivitas belajar (Anni, 2004). Hasil belajar merupakan suatu proses untuk melihat sejauh mana siswa dapat menguasai pembelajaran setelah mengikuti kegiatan proses belajar mengajar atau keberhasilan yang dicapai seorang peserta didik setelah mengikuti kegiatan pembelajaran yang ditandai dengan bentuk angka, huruf, atau simbol tertentu yang disepakati oleh pihak penyelenggara pendidikan (Mudjiono, 2009).

Berdasarkan beberapa teori di atas tentang pengertian hasil belajar, maka hasil belajar yang dimaksud dalam penelitian ini adalah hasil belajar (perubahan tingkah laku: kognitif, afektif dan psikomotorik) setelah diimplemntasikan model blended learning dalam proses pembelajaran.

Hasil belajar adalah hasil akhir yang dijadikan sebagai tolak ukur dari keberhasilan dari sebuah model, metode atau teknik pembelajaran yang diimplementasikan oleh pendidik. Peningkatan hasil belajar merupakan tujuan utama dari proses pembelajaran. Akan tetapi, berdasarkan PISA tahun 2018 bahwa kemampuan membaca anak Indonesia pada tes awal yaitu 371 dan meningkat 382 pada tahun 2003, tahun 2006 sebesar 393, tahun 2009 sebesar 403, kemudian pada tahun 2012 menurun menjadi 396 hingga menurun pada titik terendah yaitu 371 pada tahun 2018. Sementara itu, hasil belajar siswa pada pelajaran matematika pada tahun $2003=360$, kemudian naik menjadi 371, begitupun pada tahun 2009 dan 2012 naik hingga 375. Setelah memuncapk pada tahun yaitu 386, skor PISA Indonesia kembali menurun menjadi 379. Kemudian hasil belajar siswa pada pelajaran sains, pada tahun $2006=393$, tahun $2009=383$, tahun $2012=382$, kemudian pada tahun 2015 naik menjadi 403. Namun, sangat disayangkan karena pada tahun 2018 turun drastis hingga 396 (Https://Edukasi.Kompas.Com/Read/2019/12/04/13002801/Skor-Pisa-Terbaru-Indonesia-Ini-5-Pr-BesarPendidikan-Pada-Era-Nadiem-Makarim?Amp=1\&page=2. Diakses Pada Tanggal 7 Maret 2021 Pukul 11:14 $W I B)$.

Penelitian ini sangat penting untuk dilakukan karena meliputi beberapa hal. Pertama, motivasi adalah salah satu hal yang mempunyai peranan penting dalam proses pembelajaran, motivasi menumbuhkan keinginan belajar, merasa senang dan antusias untuk belajar. Peserta didik yang mempunyai motivasi kuat dalam dirinya mempunyai energi lebih dalam mengikuti pembelajaran di kelas (Sardiman, 2011). Kedua, rendahya motivasi dalam diri siswa MI/SD akan menghambat mereka mencapai hasil belajar yang baik, karena dalam melakukan proses pembelajaran siswa harus mendorong keinginannya dan menentukan arah untuk mencapai tujuan yang ingin dicapai (Emda, 2017). Pastinya dengan bimbingan oleh guru. Ketiga, Seorang peserta didik yang tidak mempunyai motivasi dalam dirinya tidak akan mengikuti proses pembelajaran dengan baik dan berdampak pada hasil belajarnya. 
6456 Efektivitas Penggunaan Model Blended Lerning dalam Meningkatkan Motivasi dan Hasil Belajar Siswa MI Darul Hikmah Bone - Mustanil, M. Samsul Hady, A. Nurul Kawakip

DOI : https://doi.org/10.31004/basicedu.v5i6.1687

Faktor pendukung motivasi belajar adalah model pembelajaran, tempat belajar, kondisi fisik siswa, kecerdasan siswa, sarana prasarana, waktu pembelajaran, kebiasaan belajar siswa, guru, orangtua, kondisi emosional siswa, dan faktor kesehatan siswa (Karimah, 2017). Dalam hal ini lebih fokus pada model pembelajaran. Proses belajar mengajar antara guru dan siswa tidak terlepas dari model pembelajaran yang digunakan secara efektif (Sardiman, 2011). Model pembelajaran pada dasarnya merupakan rancangan pembelajaran yang dilakukan oleh guru mulai dari awal hingga akhir pembelajaran yang mempunyai ciri khas tersendiri tergantung kreatifitas guru. Proses pembelajaran yang dilakukan dengan cara memadukan tatap muka langsung dan online adalah pembelajaran yang ditetapkan dalam kelas, dimana terjadi interaksi antara peserta didik dan pendidik. Pembelajaran seperti inilah yang dikenal dengan model pembelajaran blended learning.

Model pembelajaran blended learning ini bisa dijadikan solusi untuk menyelesaikan masalah di atas, karena beberapa hasil penelitian telah membuktikan bahwa blended learning dapat meningkatkan motivasi belajar siswa dibandingkan dengan jika siswa belajar secara konvensional atau belajar online secara penuh, meskipun peningkatan tersebut bervariasi (Heinze, 2008). Hal ini didukung oleh Graham yang mengatakan bisa dipastikan bahwa trend menuju sistem blended learning akan meningkat (Graham, 2006).

\section{METODE}

Penelitian ini menggunakan pendekatan kuantitatif dengan jenis penelitian ex-post facto. Penelitian expost facto merupakan penelitian empiris dan sistematis. Penelitian ex-post facto juga menggunakan kelompok pembanding yang mempunyai kemiripan karakter namun mempunyai kegiatan yang berbeda (Sappaile, 2020). Penelitian ex-post facto maksudnya dikerjakan setelah kenyataan, sering juga disebut penelitian yang dilakukan setelah kejadian (Afifah dkk, 2018). Dalam hal ini yang dimaksud adalah penggunaan model blended learning dalam proses pembelajaran di MI Darul Hikmah Bone.

Adapun rancangan dalam penelitian ini dibuatkan skema sebagai berikut:

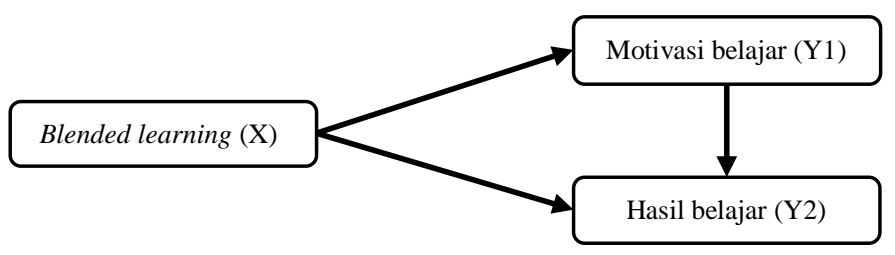

Gambar 1: Rancangan Penelitian

Populasi pada penelitian ini adalah siswa kelas IV MI Darul Hikmah Bone yang berjumlah 65 siswa. Kelas IV terbagi 3 kelas yakni (1) Tahfids, (2) Ibnu Khaldun (A), (3) Ibnu Rusyid (B). berikut disajikan tabel keadaan populasi.

Tabel 1: Keadaan Populasi

\begin{tabular}{cccccc}
\hline No & Nama Sekolah & Kelas IV & Laki-Laki & Perempuan & Jumlah \\
\hline \multirow{3}{*}{1} & \multirow{3}{*}{ MI Darul Hikmah } & Tahfidz & 7 & 9 & 16 \\
\cline { 3 - 6 } & & Ibnu Khaldun & 17 & 10 & 27 \\
\cline { 3 - 5 } & & Ibnu Rusyid & 14 & 8 & 22 \\
\cline { 3 - 5 } & \multicolumn{2}{c}{ Jumlah Keseluruhan } \\
\hline
\end{tabular}

Sumber data: TU MI darul Hikmah

Teknik sampel yang digunakan dalam penelitian ini adalah simple random sampling atau penentuan sampel dilakukan secara acak dari populasi yang ada. Akan tetapi, hal tersebut dilakukan jika anggota 
6457 Efektivitas Penggunaan Model Blended Lerning dalam Meningkatkan Motivasi dan Hasil Belajar Siswa MI Darul Hikmah Bone - Mustanil, M. Samsul Hady, A. Nurul Kawakip

DOI : https://doi.org/10.31004/basicedu.v5i6.1687

populasi dianggap homogen. Sampel pada penelitian ini yaitu kelas IVA (Ibnu Khaldun) dan IVB (Ibnu Rusyid) yang berjumlah 49 siswa. Berikut disajikan tabel keadaan sampel pada penelitian ini:

Tabel 2: Keadaan Sampel

\begin{tabular}{cccccc}
\hline No & Nama Sekolah & Kelas IV & Laki-Laki & Perempuan & Jumlah \\
\hline \multirow{3}{*}{1} & MI Darul Hikmah & Ibnu Khaldun & 17 & 10 & 27 \\
\cline { 3 - 5 } & & Ibnu Rusyid & 14 & 8 & 22 \\
\cline { 3 - 5 } & \multicolumn{3}{c}{ Jumlah Keseluruhan } \\
\hline \multicolumn{5}{c}{ Sumber data: TU MI Darul Hikmah }
\end{tabular}

Teknik pengumpulan data yang digunakan adalah dokumentasi, angket dan soal. Teknik analisis data SEM-PLS dengan bantuan aplikasi smartPLS versi 3.0. Berikut merupakan model PLS yang digunakan

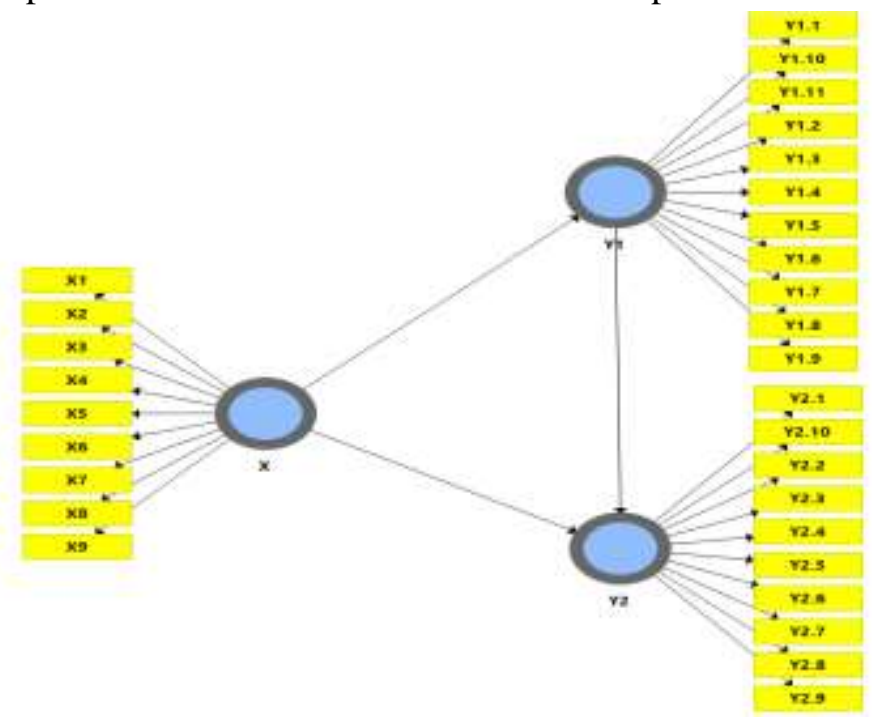

Gambar 2: Model PLS yang dibentuk

\section{HASIL DAN PEMBAHASAN}

Penelitian ini mengukur hasil belajar siswa pada pembelajaran tematik tema 1 sub tema 1 sampai 3 . Instrument yang digunakan adalah soal tes yang telah diuji cobakan kepada siswa SD INP 12/79 Pattuku Limpoe dan dinyatakan valid setelah diolah menggunakan SmartPLS. Adapun hasilnya dapat dilihat pada tabel berikut:

Tabel 3: Distribusi Hasil Belajar Siswa

\begin{tabular}{|c|c|c|c|c|}
\hline No & Interval & Frekuensi & Persentase & Predikat \\
\hline 1 & $90-100$ & 37 & $77 \%$ & Sangat Tinggi \\
\hline 2 & $75-89$ & 3 & $6 \%$ & Tinggi \\
\hline 3 & $55-74$ & 1 & $2 \%$ & Sedang \\
\hline 4 & $40-54$ & 1 & $2 \%$ & Rendah \\
\hline 5 & $0-39$ & 6 & $13 \%$ & Sangat Rendah \\
\hline \multicolumn{2}{|c|}{ Jumlah } & 48 & $100 \%$ & \\
\hline
\end{tabular}

Berdasarkan tabel 3 hasil belajar siswa di atas, dapat dinyatakan bahwa 37 siswa mendapat nilai antara 90-100 dengan predikat sangat tinggi. 3 siswa memperoleh predikat tinggi, masing-masing 1 siswa 
6458 Efektivitas Penggunaan Model Blended Lerning dalam Meningkatkan Motivasi dan Hasil Belajar Siswa MI Darul Hikmah Bone - Mustanil, M. Samsul Hady, A. Nurul Kawakip

DOI : https://doi.org/10.31004/basicedu.v5i6.1687

memperoleh predikat sedang dan rendah serta 6 siswa yang memperoleh predikat sangat rendah. Jumlah persentase paling tinggi sebesar $77 \%$ dan terendah $2 \%$. Dengan demikian, dapat disimpulkan bahwa dengan penggunaan model blended learning, dominan siswa dapat nilai di atas $\mathrm{KKM}=72$ dengan kategori sangat tinggi.

Data yang diolah merupakan data yang telah melewati tahap validitas dan reabilitas instrument yang yang diuji menggunakan outer model. Selanjutnya mengestimasi model PLS dengan bootstrapping. Pada tahap ini dilakukan analisis data untuk menjawab hipotesis yang diajukan.

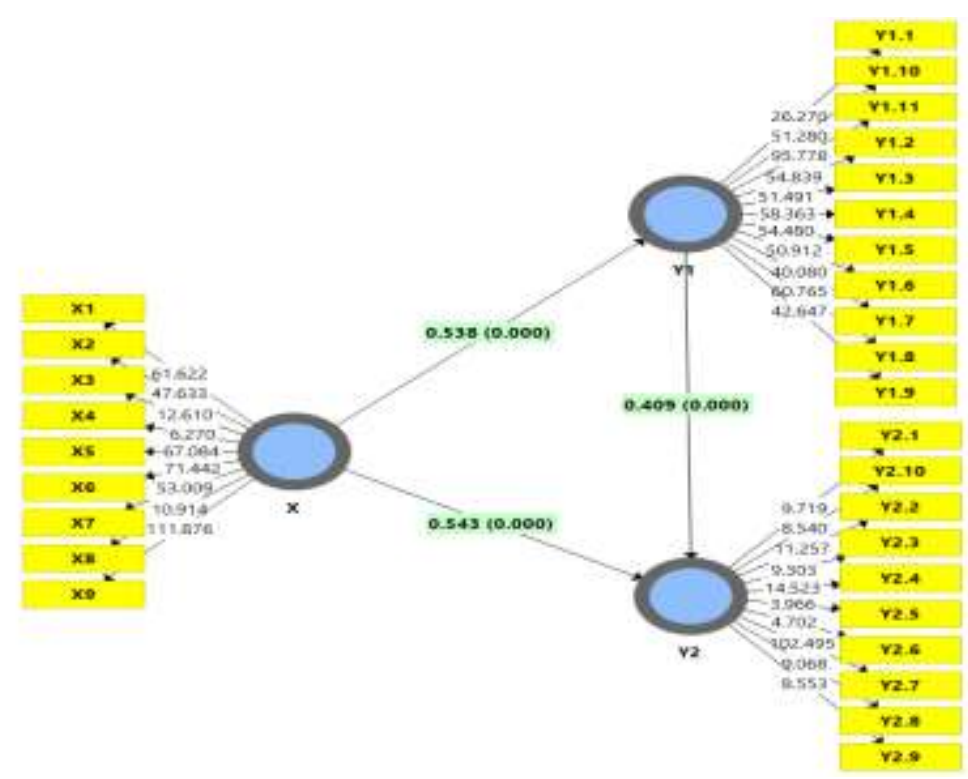

Gambar 3: Model PLS-Bootsrapping

Ketiga, menentukan model fit. Syarat model dikatakan fit apabila Standardized Root Mean Square Residual (SRMR model) $<0,10$, model perfect fit jika SRMR model $<0,08$.

Tabel 4: Goodness of Fit Model

\begin{tabular}{lcc}
\hline & $\begin{array}{c}\text { Saturated } \\
\text { Model }\end{array}$ & $\begin{array}{c}\text { Estimated } \\
\text { Model }\end{array}$ \\
\hline SRMR & 0,056 & 0,056 \\
\hline d_ULS & 1,481 & 1,481 \\
\hline d_G & 4,945 & 4,945 \\
\hline Chi-Square & 778,958 & 778,958 \\
\hline NFI & 0,722 & 0,722 \\
\hline
\end{tabular}

Berdasarkan tabel 4 di atas, dapat dilihat nilai Standardized Root Mean Square Residual (SRMR) = 0.056 lebih kecil dari 0.10 dan $0.08(0,056<0,08)$. Hal ini menandakan bahwa model fit yang dibentuk masuk dalam kategori model perfect fit. Setelah itu melihat kekuatan model yang dibangun dapat dilihat pada tabel berikut:

Tabel 5: Kekuatan Model

\begin{tabular}{lcc}
\hline & $\boldsymbol{R}$ Square & $\boldsymbol{R}$ Square Adjusted \\
\hline Y1 & 0,290 & 0,274 \\
\hline Y2 & 0,702 & 0,689 \\
\hline
\end{tabular}


6459 Efektivitas Penggunaan Model Blended Lerning dalam Meningkatkan Motivasi dan Hasil Belajar Siswa MI Darul Hikmah Bone - Mustanil, M. Samsul Hady, A. Nurul Kawakip

DOI : https://doi.org/10.31004/basicedu.v5i6.1687

Selain tabel kekuatan model di atas, juga dapa dilihat grafik $R$ Square dan $R$ Square Adjusted sebagai berikut:
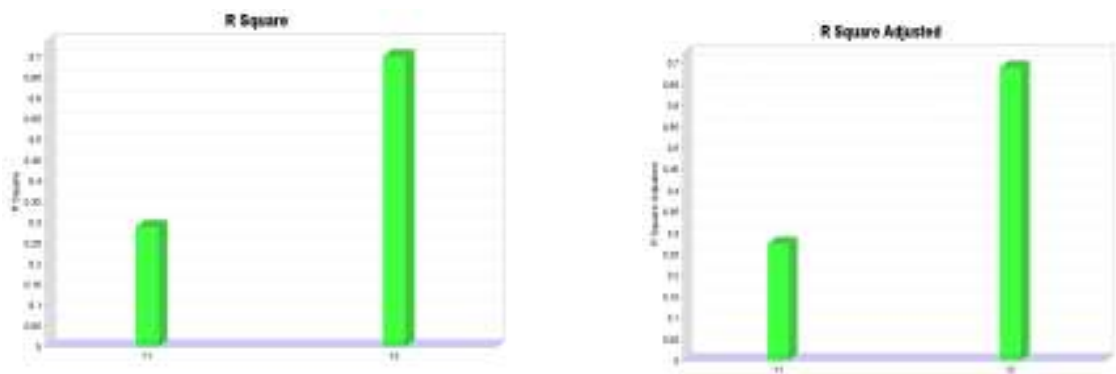

Berdasarkan tabel 5 dan grafik di atas, dapat dinyatakan bahwa R square motivasi belajar $\mathrm{Y} 1=0,290$, berarti model cukup kuat (moderate) saat digunakan untuk memprediksi motivasi belajar (Y1) dari blended learning $(\mathrm{X})$ dan $\mathrm{R}$ square hasil belajar $(\mathrm{Y} 2)=0,702$, berarti model kuat (strong) saat digunakan untuk memprediksi hasil belajar (Y2) dari blended learning (X) dan motivasi belajar (Y1).

Keempat, menentukan Predictive Relevance Model. Menurut Chin (1998), nilai Q square dikategorikan dalam tiga kategori yaitu kecil, sedang dan besar.

Tabel 6: Predictive Relevance Model

\begin{tabular}{lccc}
\hline & SSO & SSE & $\mathbf{Q}^{2}(=\mathbf{1 - S S E} / \mathbf{S S O})$ \\
$\mathbf{X}$ & 432,000 & 432,000 & \\
Y1 & 528,000 & 398,434 & 0,245 \\
Y2 & 480,000 & 249,316 & 0,481 \\
\hline
\end{tabular}

Berdasarkan tabel di atas, dapat dinyatakan bahwa Q Square motivasi belajar (Y1) $=0,245$ berarti model memiliki predictive relevance sedang saat memprediksi motivasi belajar (Y1) dari nilai blended learning (X). Dan Q Square hasil belajar (Y2) $=0,481$ berarti model memiliki predictive relevance tinggi saat digunakan memprediksi hasil belajar (Y2) dari nilai blended learning (X) dan motivasi belajar (Y1).

Uji hipotesis yang dilakukan terbagi atas dua bagian yakni pengujian secara langsung dan pengujian tidak langsung.Pengujian pengaruh langsung dilakukan untuk mengetahui pengaruh positif atau negatif serta signifikansi dari variabel independen (X) terhadap variabel dependen (Y1 \& Y2) secara langsung.

\section{Uji pengaruh langsung.}

Tabel 7: Uji Pengaruh Langsung

\begin{tabular}{lccccc}
\hline & $\begin{array}{c}\text { Original } \\
\text { Sample } \\
(\mathbf{O})\end{array}$ & $\begin{array}{c}\text { Sample } \\
\text { Mean }(\mathbf{M})\end{array}$ & $\begin{array}{c}\text { Standard } \\
\text { Deviation } \\
(\text { STDEV })\end{array}$ & $\begin{array}{c}\text { T Statistics } \\
(\mid \mathbf{O} / \text { STDEV } \mid)\end{array}$ & P Values \\
\hline $\mathbf{X} \rightarrow$ Y1 & 0,538 & 0,508 & 0,138 & 3,889 & $\mathbf{0 , 0 0 0}$ \\
\hline $\mathbf{X} \rightarrow \mathbf{Y 2}$ & 0,543 & 0,547 & 0,071 & 7,614 & $\mathbf{0 , 0 0 0}$ \\
\hline $\mathbf{Y 1 ~} \rightarrow$ Y2 & 0,409 & 0,407 & 0,075 & 5,486 & $\mathbf{0 , 0 0 0}$ \\
\hline
\end{tabular}

Berdasarkan tabel 7 di atas, dapat dinyatakan sebagai berikut:

$\mathrm{X} \rightarrow \mathrm{Y} 1$

Nilai $P$ value $=0,000 ;$ T statistik $=3,889$, oleh karena nilai $P$ value $<0,05$ dan T statistik $>1,96$ serta koefisien jalur positif sebesar 0,538 berarti bahwa blended learning $(\mathrm{X})$ berpengaruh positif dan signifikan terhadap motivasi belajar (Y1), semakin tinggi blended learning (X) maka semakin tinggi motivasi belajar (Y1). 
6460 Efektivitas Penggunaan Model Blended Lerning dalam Meningkatkan Motivasi dan Hasil Belajar Siswa MI Darul Hikmah Bone - Mustanil, M. Samsul Hady, A. Nurul Kawakip

DOI : https://doi.org/10.31004/basicedu.v5i6.1687

Penelitian ini mendukung pada penelitian sebelumnya (Abroto dkk, 2021) yang menemukan bahwa blended learning berpengaruh terhadap motivasi belajar siswa. Seperti penelitian yang dilakukan oleh Abroto dkk, adanya peningkatan motivasi belajar siswa yang menggunakan model pembelajaran blended learning, sehingga guru harus memperhatikan model yang sesuai dengan kebutuhan belajar siswa, pelaksanaan model blended learning merupakan salah satu solusi bagi siswa yang memiliki motivasi rendah dan sudah terbukti bahwa terdapat perbedaan signifikan motivasi belajar bagi peserta didik yang belajar dengan model blended learning dan model konvensional. Hal tersebut selaras dengan pendapat Desy dalam penelitiannya terdapat peningkatan motivasi belajar secara signifikan akibat penggunaan model blended leaning dalam proses pembelajaran. Setidaknya ada enam indikator motivasi belajar 1) hasrat dan keinginan berhasil, 2) dorongan dan kebutuhan pelajaran, 3) harapan dan cita-cita masa depan, 4) penghargaan dalam belajar, 5) kegiatan yang menarik dalam belajar, dan 6) lingkungan belajar yang kondusif. Model blended learning merupakan model pembelajaran yang menarik dalam belajar karena adanya perpaduan tatap muka dan online yang membuat anak milenial lebih semangat dalam belajarnya. Peserta didik bisa belajar kapanpun dan dimana saja dengan bantuan internet serta dapat kapan saja menanyakan materi yang belum dipahami kepada guru melalui form yang telah dibentuk (Indriani, 2019).

Berdasarkan temuan di atas, dapat dipahami bahwa model blended learning merupakan salah satu model pembelajaran yang berpengaruh terhadap motivasi belajar siswa. Dengan demikian, model pembelajaran ini sangat membantu siswa dalam meningkatkan motivasi belajar sehingga siswa dapat memecahkan kesulitan yang ditemukan dalam pembelajaran. Oleh karena itu, model blended learning harus diterapkan dalam proses pembelajaran agar siswa mempunyai motivasi belajar yang baik.

\section{$\mathrm{X} \rightarrow \mathrm{Y} 2$}

Nilai $P$ value $=0,000 ;$ T statistik $=7,614$, oleh karena nilai $P$ value $<0,05$ dan T statistik $>1,96$ serta koefisien jalur positif sebesar 0,543 berarti bahwa blended learning $(\mathrm{X})$ berpengaruh positif dan signifikan terhadap hasil belajar (Y2), semakin tinggi blended learning (X) maka semakin tinggi hasil belajar (Y2).

Penemuan ini mendukung hasil penelitian terdahulu seperti penelitian yang ditulis (Levianti dkk, 2021) penelitian yang dilakukan di Sekolah Dasar mengatakan bahwa model pembelajaran blended learning hasil belajar siswa pada tema lingkungan sahabat kita subtema perubahan lingkungan. Sementara penelitian Gede pada tahun 2012 menyatakan terdapat perbedaan hasil belajar antara peserta didik yang mengikuti blended learning dengan siswa yang mengikuti pembelajaran konvensional. Pada model blended learning siswa dituntun untuk belajar secara mandiri dan diberikan materi pembelajaran yang dirancang sedemikian rupa sehingga siswa tertarik untuk belajar. Materi pembelajaran disampaikan dengan bantuan media elektronik yang disampaikan menggunakan aplikasi moodle. Media elektronik dirancang sedemikian rupa sehingga berfungsi semaksimal mungkin. Materi pelajaran yang bersifat abstrak divisualisasi sehingga siswa lebih mudah memahaminya. Penerapan pembelajaran dengan model blended learning berlangsung baik di kelas maupun di luar kelas (Sandi, 2012).

Berdasarkan penemuan di atas, dapat dipahami bahwa model pembelajaran blended learning berpengaruh terhadap hasil belajar siswa. Dengan demikian, model pembelajaran ini dapat membantu siswa untuk meningkatkan hasil belajarnya sehingga dapat mecapai KKM yang telah ditentukan. Oleh karena itu, model pembelajaran ini harus diterapkan dalam proses belajar mengajar untuk mencapai tujuan pembelajaran.

\section{$\mathrm{Y} 1 \rightarrow \mathrm{Y} 2$}

Nilai $P$ value $=0,000 ;$ T statistik $=5,486$, oleh karena nilai $P$ value $<0,05$ dan T statistik $>1,96$ serta koefisien jalur positif sebesar 0,409 berarti bahwa motivasi belajar (Y1) berpengaruh positif dan signifikan terhadap hasil belajar (Y2), semakin tinggi motivasi belajar (Y1) maka semakin tinggi hasil belajar (Y2).

Adapun hasil penelitian yang didukung oleh penelitian di atas yaitu penelitian yang dilakukan oleh (Warti, 2016) yang dilakukan di SD pada pelajaran matematika mengatakan bahwa semakin tinggi motivasi belajar semakin baik pula hasil belajar matematikanya. Sementara itu, Hendra mengatakan bahwa faktor 
6461 Efektivitas Penggunaan Model Blended Lerning dalam Meningkatkan Motivasi dan Hasil Belajar Siswa MI Darul Hikmah Bone - Mustanil, M. Samsul Hady, A. Nurul Kawakip

DOI : https://doi.org/10.31004/basicedu.v5i6.1687

intern yaitu motivasi belajar mempunyai pengaruh yang positif dan signifikan terhadap hasil belajar siswa. Kekuatan hubungan motivasi belajar dengan hasil belajar siswa adalah sangat kuat. Dengan memberikan motivasi-motivasi yang kuat dan tinggi dalam pembelajaran maka akan memberikan dampak yang bersifat positif dan signifikan terhadap hasil belajar siswa SMK. Sehingga optimalisasi tujuan belajar berupa hasil belajar siswa dapat tercapai.

Hasil penelitian lain yang ditulis (Sobandi, 2017) mengatakan bahwa Hasil penelitian yang menunjukkan bahwa terdapat pengaruh motivasi belajar terhadap hasil belajar siswa kelas VIII MTs Negeri 1 Pangandaran mengandung implikasi bahwa untuk meningkatkan hasil belajar Bahasa Indonesia dapat dilakukan dengan mengajak siswa mengenali dan memahami cara belajarnya dan mengoptimalkan cara belajar tersebut semaksimal mungkin. Selain hal tersebut, untuk meningkatkan hasil belajar Bahasa Indonesia juga dilakukan dengan mengupayakan meningkatkan motivasi instrinsik siswa untuk belajar.

Dari hasil penelitian dapat diketahui bahwa motivasi belajar mempunyai kontribusi terhadap peningkatan hasil belajar siswa. Oleh karena itu, guru harus mengajar harus memahami cara untuk memotivasi siswa agar mampu belajar dengan baik. Diantaraya dapat melalui pemberian hadiah, pemberian ucapan, adanya kuis-kuis yang memotivasi siswa dalam belajar.

\section{Pengujian Pengaruh Tidak Langsung}

Tujuan dilakukan uji pengaruh tidak langsung adalah untuk mengetahui motivasi belajar (Y1) dapat menjadi variabel mediasi dalam meningkatkan hasil belajar (Y2) dengan menggunakan model blended learning $(\mathrm{X})$

Tabel 8: Uji Pengaruh Tidak Langsung

\begin{tabular}{cccccc}
\hline & $\begin{array}{c}\text { Original } \\
\text { Sample }(\mathrm{O})\end{array}$ & $\begin{array}{c}\text { Sample } \\
\text { Mean }(M)\end{array}$ & $\begin{array}{c}\text { Standard Deviation } \\
(\text { STDEV })\end{array}$ & $\begin{array}{c}\text { T Statistics } \\
(\mid \text { OSTDEV } \mid)\end{array}$ & P Values \\
\hline $\mathrm{X} \rightarrow \mathrm{Y} 1 \rightarrow \mathrm{Y} 2$ & 0,220 & 0,208 & 0,072 & 3,079 & $\mathbf{0 , 0 0 2}$ \\
\hline
\end{tabular}

Berdasarkan tabel 8 di atas, dapat dinyatakan bahwa nilai $P$ value pengaruh tidak langsung $\mathrm{X} \rightarrow \mathrm{Y} 1 \rightarrow$ Y2 sebesar 0,002 dengan T statistik 3,079, nilai $P$ value $<0,05$, T statistic $>1,96$ menunjukkan bahwa secara signifikan $\mathrm{X}$ dapat berpengaruh tidak langsung terhadap Y2 melalui Y1

Hasil penelitian ini didukung oleh (Sihkabuden, 2011) mahasiswa S3 Universitas Negeri Malang dalam disertasinya mengatakan bahwa penerapan pembelajaran dengan pembelajaran berbasis web (blended learning) maupun tatap muka dengan caramah berbantuan slide power point serta pembelajaran face to face akan memberikan hasil yang lebih baik pada pebelajar dengan motivasi berprestasi tinggi.

Berdasar pada pendapat tersebut, menandakan bahwa pembelajaran dengan menggunakan blended learning efektif digunakan oleh guru untuk meningkatkan hasil belajar melalui motivasi belajar siswa. Artinya, jika siswa memiliki motivasi tinggi dalam pembelajaran model blended learning maka akan berdampak positif terhadap hasil belajar siswa, mencapai nilai Kriteria Ketuntasan Minimum yang telah ditentukan, dimana KKM pada MI Darul Hikmah pada pembelajaran tematik yakni 72. Selain daripada itu, komponen utama yang harus terpenuhi dalam proses pembelajaran adalah tercapainya tujuan pembelajaran dengan baik.

\section{KESIMPULAN}

Efektivitas penggunaan model blended learning dalam meningkatkan hasil belajar melalui motivasi belajar siswa kelas IV MI Darul Hikmah Bone dengan nilai $P$ value $0.002<0.05$. Artinya, model blended learning memiliki efektivitas positif dan signifikan dalam meningkatkan hasil belajar melalui motivasi belajar. Hasil pembahasan menunjukkan bahwa pada langkah-langkah pendayagunaan model blended learning ada 
6462 Efektivitas Penggunaan Model Blended Lerning dalam Meningkatkan Motivasi dan Hasil Belajar Siswa MI Darul Hikmah Bone - Mustanil, M. Samsul Hady, A. Nurul Kawakip

DOI : https://doi.org/10.31004/basicedu.v5i6.1687

stimulus terhadap motivasi belajar yang membuat siswa lebih semangat belajar dan dikatakan menjadi jembatan atau mediasi terhadap peningkatan hasil belajar siswa yang ditandai dengan tercapainya nilai diatas KKM yang telah ditentukan. Dengan demikian, semakin tinggi motivasi belajar siswa baik secara internal maupun secara eksternal, maka semakin baik hasil belajar yang diperoleh sehingga tujuan pembelajaran dapat terpenuhi.

\section{DAFTAR PUSTAKA}

A., Heinze. (2008). Blended Learning: An Interpretive Action Reseach Study. Disertasi Doktor, Tidak Diterbitkan, University Of Salford, Salford, Uk.

Abroto Dkk. (2021). Pengaruh Metode Blended Learning Dalam Meningkatkan Motivasi Dan Hasil Belajar Siswa Sekolah Dasar. Edukatif: Jurnal Ilmu Pendidikan, 3(5), 1993-2000.

Afifah Dkk. (2018). Pengaruh Blended Learning Terhadap Motivasi Belajar Mahasiswa Pada Mata Kuliah Metodologi Penelitian Jurusan Pendidikan Ekonomi Fe Unp. 1(1), 33.

Agustina. (2011). Pengaruh Motivasi Belajar Siswa Terhadap Prestasi Belajar Ipa Di Sekolah Dasar (Studi Kasus Terhadap Siswa Kelas Iv Sdn Tarumanagara Kecamatan Tawang Kota Tasikmalaya). Jurnal Penelitian Pendidikan, 12(1).

Anni, C. T. (2004). Psikologi Belajar. Ikip Semarang Press.

C, Graham. (2006). Blended Learning Systems: Definition, Current Trends, And Future Directions. Dalam C.

J. Bonk \& C. R. Graham (Eds), The Handbook Of Blended Learning: Global Perspectives, Local Designs. San Francisco, Ca: John Wiley \& Sons, Inc.

Darmawati, J. (2013). Pengaruh Motivasi Dan Gaya Belajar Terhadap Prestasi Belajar Ekonomi Siswa Sma Negeri Di Kota Tuban. Jurnal Ekonomi Pendidikan Dan Kewirausahaan, 1(1).

Emda, A. (2017). Kedudukan Motivasi Belajar Siswa Dalam Pembelajaran. Lantanida Journal, 5(2).

Https://Edukasi.Kompas.Com/Read/2019/12/04/13002801/Skor-Pisa-Terbaru-Indonesia-Ini-5-Pr-BesarPendidikan-Pada-Era-Nadiem-Makarim?Amp=1\&Page=2. Diakses Pada Tanggal 7 Maret 2021 Pukul 11:14 Wib. (N.D.).

Indriani, D. (2019). Pengaruh Model Blended Learning Terhadap Motivasi Dan Prestasi Belajar Siswa Sekolah Dasar. Prosiding Seminar Nasional Fakultas Ilmu Sosial Universitas Negeri Medan, 3, 851-854.

Karimah, R. (2017). Faktor-Faktor Yang Mempengaruhi Rendahnya Motivasi Belajar Siswa. Jurnal AtTaqaddum, 10(1).

Levianti Dkk. (2021). The Effect Of Blended Learning Model On Student's Learning Outcomes On The Theme Of "Lingkungan Sahabat Kita" At Grade V Sd. Jurnal Pajar (Pendidikan Dan Pengajaran), 5(5).

Mafirah, S. (2020). Efektivitas Penerapan Blended Learning Dalam Meningkatkan Motivasi Belajar Mahasiswa Sastra Inggris Universitas Khairun. Journal Of Language, Literature And Linguistics, 1(2).

Mudjiono, D. (2009). Belajar Dan Pembelajaran. Pt Rineka Cipta.

Purwanto. (2016). Evaluasi Hasil Belajar. Pustaka Belajar.

Purwanto, M. N. (2002). Psikologi Pendidikan. Rosda Karya.

Sandi, G. (2012). Pengaruh Blended Learning Terhadap Hasil Belajar Kimia Ditinjau Dari Kemandirian Siswa. Jurnal Pendidikan Dan Pengajaran, 45(3), 241-251.

Sanjaya, W. (2008). Kurikulum Dan Pembelajaran. Kencana Prenada Media Group.

Santoso, D. T. (2016). Rendahnya Motivasi Belajar Siswa Dan Solusi Penanganan Pada Siswa Kelas Xi Jurusan Teknik Sepeda Motor. Jurnal Pendidikan Teknik Otomotif Edisi Xiii, 2. 
6463 Efektivitas Penggunaan Model Blended Lerning dalam Meningkatkan Motivasi dan Hasil Belajar Siswa MI Darul Hikmah Bone - Mustanil, M. Samsul Hady, A. Nurul Kawakip

DOI : https://doi.org/10.31004/basicedu.v5i6.1687

Sappaile, B. I. (2020). Konsep Penelitian Ex-Post Facto. Jurnal Pendidikan Matematika, 1(2), 106.

Sardiman. (2011). Interaksi Dan Motivasi Belajar Mengajar. Rajawali Pers.

Sihkabuden. (2011). Pengaruh Interaktif Strategi Pembelajaran Blended Learning Dan Motivasi Berprestasi Terhadap Hasil Belajar Mahasiswa Tep Fip-Um. Universitas Negeri Malang, Disertasi.

Sobandi, R. (2017). Pengaruh Motivasi Belajar Terhadap Hasil Belajar Bahasa Indonesia Pada Siswa Kelas Vii Mts Negeri Pangandaran. Jurnal Diksatrasia, 1(2), 309.

Sudjana, N. (2011). Penilaian Hasil Dan Proses Belajar Mengajar. Rosda Karya.

Sukmadinata, N. S. (2009). Landasan Psikologi Proses Pendidikan. Pt Remaja Rosdakarya.

Tim Penyusun Pusat Bahasa (Mendikbud). (2007). Kamus Besar Bahasa Indonesia. Balai Pustaka.

Warti, E. (2016). Pengaruh Motivasi Belajar Siswa Terhadap Hasil Belajar Matematika Siswa Di Sd Angkasa 10 Halim Perdana Kusuma Jakarta Timur. Jurnal Pendidikan Matematika Stkip Garut, 5.

Winataputra. (2008). Teori Belajar Dan Pembelajaran. Universitas Terbuka. 